University of Nebraska - Lincoln

DigitalCommons@University of Nebraska - Lincoln

Marketing Department Faculty Publications

Marketing Department (CBA)

2-2005

\title{
A Consumer-Behavior Perspective on Intimate Partner Violence
}

Debra Lynn Stephens

University of Portland

Ronald Paul Hill

University of South Florida, St. Petersburg

James W. Gentry

University of Nebraska-Lincoln, jgentry@unl.edu

Follow this and additional works at: https://digitalcommons.unl.edu/marketingfacpub

Part of the Marketing Commons

Stephens, Debra Lynn; Hill, Ronald Paul; and Gentry, James W., "A Consumer-Behavior Perspective on Intimate Partner Violence" (2005). Marketing Department Faculty Publications. 7.

https://digitalcommons.unl.edu/marketingfacpub/7

This Article is brought to you for free and open access by the Marketing Department (CBA) at DigitalCommons@University of Nebraska - Lincoln. It has been accepted for inclusion in Marketing Department Faculty Publications by an authorized administrator of DigitalCommons@University of Nebraska - Lincoln. 
Published in Journal of Contemporary Ethnography 34:1 (February 2005), pp. 36-67; doi: 10.1177/0891241604271333 Copyright (C) 2005 Sage Publications. Used by permission. http://jce.sagepub.com/cgi/content/abstract/34/1/36

The authors offer a special thanks to Scott Hunt and Robert Benford for their support and guidance and to three anonymous reviewers for their comments on earlier versions. This article is dedicated to the abused women who shared their experiences with us.

"When a batterer systematically destroys the possessions that are both means to and symbolic of his partner's autonomy, he is getting rid of proof of her agency."

\title{
A Consumer-Behavior Perspective on Intimate Partner Violence
}

\author{
Debra Lynn Stephens \\ Ronald Paul Hill \\ James W. Gentry
}

Debra Lynn Stephens is associate professor of marketing in the Dr. Robert B. Pamplin, Jr. School of Business Administration at the University of Portland. She received her Ph.D. in psychology from the University of Chicago and was retrained in clinical practice at George Washington University. Her scholarly interests include abused and neglected women and children.

Ronald Paul Hill is Bank of America professor of corporate social responsibility and founding dean, College of Business, University of South Florida, St. Petersburg. His research focuses on a variety of social and public policy issues involving the intersection between vulnerable consumer populations and organizations. A portion of this work is summarized in a 2001 volume titled Surviving in a Material World: The Lived Experience of People in Poverty by the University of Notre Dame Press. 
James W. Gentry is the Maurice J. and Alice Hollman professor of marketing at University of Nebraska-Lincoln. He has taught at several leading research institutions, including the University of Wisconsin at Madison and Oklahoma State University. He is one of the senior scholars in the consumer-behavior field, with a special focus on marketing communications and global contexts.

\begin{abstract}
This research examines women's experiences of and responses to intimate partner violence using the perspective of the extended self. From in-depth interviews with a demographically diverse group of women in the United States, the primary theme to emerge was that chronic abuse is experienced as the male partner's ongoing campaign to incorporate the abused woman into his extended self, by appropriating or destroying the aspects of her that give her autonomy. The most important implication for agencies serving abused women is that many of their clients are faced with the daunting task of repairing or reconstructing their core and extended selves, a process that may necessitate the longterm commitment of agency resources without the imposition of restricted, institutionally imposed identities that would serve only to impede clients' reclamation of their autonomy.
\end{abstract}

Keywords: consumption, extended self, domestic violence, social services

7 he household has long been viewed as the primary consuming unit within most cultures (Alderson 1957). While the nature of households has changed greatly across the Western world, deviating from the traditional two-parent family of the 1950s, much consumer- behavior theory and research still focuses on white, middle-class heterosexual experiences (Bristor and Fischer 1995). For example, researchers who examine consumption have written little about experiences in nontraditional, dysfunctional, or traumatized families (see Hill 1991, 1992; McAlexander, Schouten, and Roberts 1993; Rindfleisch, Burroughs, and Denton 1997 for notable exceptions).

This article focuses on households disrupted by male-on-female intimate partner violence. The Women's Health and Development Unit (WHD) of the World Health Organization (WHO) recently reported that men's violence against their female partners directly affects 10 percent 
to 69 percent of females in the nations surveyed and that 40 percent to 70 percent of females murdered were killed by husbands or boyfriends (WHO 2002). The WHD posits this cultural and intergenerational problem as one of the major human rights dilemmas today.

The current study employs the extended-self paradigm (Belk 1988) to achieve a deeper understanding of women's experiences of and responses to partner violence. The theory of the extended self may help explain why many cases of intimate partner violence are not subject to the seemingly obvious solution of helping the woman escape and prosecuting the perpetrator. And it may help formulate agency policies and practices that take into account the complexities of clients' experiences and perspectives.

The first section of the article briefly discusses the prevalence of intimate partner violence in the United States and the circumstances under which it is most likely to occur. The second section describes the extended-self paradigm within consumer research that this study employs to acquire a deeper understanding of how women experience and interpret the violence of their male partners. The third section presents the study itself, and the final section explores its implications for agencies that serve battered women.

\section{Male-on-Female Intimate Partner Violence}

Physical violence includes acts such as shoving, slapping, punching, kicking, choking, throwing, scalding, cutting, smothering, or biting (Koss et al. 1994). A pattern of physical aggression is often accompanied by sexual assault and even more frequently by psychological abusethat is, isolating a woman from friends and family, obstructing her attempts to obtain medical or social assistance, threatening to harm or actually harming property or pets (Ascione 1998), and verbally threatening or demeaning her (WHO 2002). An estimated 588,490 American women were victimized (physically assaulted, sexually assaulted, or robbed) by an intimate partner in 2001 (Rennison 2003). And in recent years, an estimated 33 percent of female murder victims were killed by current or former intimate partners (Rennison 2003).

The annual National Crime Victimization Survey (NCVS) is one of the largest ongoing forums for crime victims to describe the nature and im- 
pact of criminal victimizations, including those not reported to the police; in addition, the survey collects victim and offender demographic characteristics and abuse-related histories (Rennison 2001). The 1999 NCVS results indicated that intimate partner violence against women varies with age, household income, and history of abuse. Younger women are more vulnerable than are older ones to intimate partner violence; the overall per capita rate in 1999 was 5.8 victimizations per 1,000, while for women ages sixteen to twenty-four, it was 15.6 per 1,000. Household income also varies with violence rates; NCVS findings for 1993-1999 indicate that lower household incomes result in higher rates of intimate violence. In addition to demographic characteristics, a history of childhood abuse has been found to be associated with a significantly increased likelihood of victimization by a male partner (Tjaden and Thoennes 2000).

If a woman's partner is verbally abusive, the odds that he will become physically violent increase significantly (Tjaden and Thoennes 2000). Recent clinical studies indicate that men who assault their female partners use physical violence as part of a systematic pattern of dominance and control. Such men view female autonomy as male loss of control and use violence both to discharge anger in response to a perceived loss of power and to reestablish dominance over their partners (Gagne 1992).

It has been argued that male-on-female intimate violence has much in common with slavery (see Dobash and Dobash 1979). Like slave masters, male perpetrators employ threats and physical violence to terrorize their partners into submission, and like slaves, many women risk greater violence if they attempt to escape their assailants. The fact that a woman may have freely chosen to enter into cohabitation or marriage does not imply that she continues to be a free agent when the relationship becomes coercive. Indeed, until the passage of the Nineteenth Amendment to the U.S. Constitution, upon marriage a woman entered into the condition of coverture, under which her husband had legal control of her and her estate, and she and her husband had one identity under the law. In effect, the woman became a part of her husband when they married, and he became the legal head of the family. In intimate partner violence, the perpetrator relates to his partner as if he owns her and she has no right to an identity or autonomy apart from him.

To explore the underlying theme of ownership in intimate partner violence, this study draws from consumer research that explores the deep meaning of possessions as parts of the individual's extended self. The 
theoretical paradigm of the extended self (Belk 1988) will be discussed next, along with research on the processes by which possessions become incorporated into and lost, or expelled from, the extended self.

\title{
Possessions and the Extended Self
}

Mounting evidence from consumer research indicates that humans develop, maintain, and transform their self-identities in part by acquiring, caring for, using, and disposing of possessions (Belk 1988; Morgan 1993; Sayre 1994; Young 1991). Here, self-identity, self-concept, and self-perception will be used interchangeably to refer to the relatively enduring personal traits and social roles individuals ascribe to themselves (Terry, Hogg, and White 2000). The idea that one's possessions may be viewed as a part of self-identity is not new; in his widely cited chapter on the self, William James $(1890,291-92)$ asserted that

\begin{abstract}
a man's Self is the sum total of all that he CAN call his. Not only his body and his psychic powers, but his clothes and his house, his wife and children, his ancestors and friends, his reputation and works, his lands, and yacht, and bank account. All these things give him the same emotions. If they wax and prosper, he feels triumphant; if they dwindle and die away, he feels cast down, not necessarily in the degree for each thing, but in much the same way for all.
\end{abstract}

Empirical research supports James's contention that the body and mind, personal traits, material possessions, the home, and friends and relations are all commonly perceived as parts of self (Ellis 1985; McClelland 1951; Prelinger 1959). Prelinger (1959) found that control is a central component of those possessions we view as extensions of ourselves; the more we feel that we control, or are controlled by, an object or living being, the stronger our perception that it is a part of us (Belk 1988; Prelinger 1959). Belk (1988) refers to these special possessions as means of physically and symbolically extending the self. For example, parents may view children as symbolic extensions of their selves into the future; weapons and tools provide physical extensions of power and control over the external environment; cars, clothing, homes, and spouses or partners may symbolically extend our agency in the world. 
If indeed certain possessions are parts of our self-identity, their involuntary loss should lead to a diminution of sense of self. In-depth interviews with burglary victims revealed that many felt personally violated (Belk 1988). Victims of natural disasters such as firestorms (Sayre 1994) and mudslides (McLeod 1984) revealed feelings of grief similar to those expressed upon losing a loved one. Also, institutions such as mental hospitals, boarding schools, military training academies, shelters for the homeless and abused, and prisons routinely restrict or remove possessions that symbolize the individual's identity outside the institutional boundaries (Goffman 1961; Snyder and Fromkin 1981). Prisons, military training facilities, and monasteries may do so with the intent of diminishing the individual's sense of self in service to a collective identity (Snyder and Fromkin 1981). Institutions such as mental hospitals, shelters, and retirement or nursing homes may unintentionally diminish residents' self-identities because of restrictions necessitated by space limitations or safety considerations.

An individual or group may deliberately damage or destroy another's possessions in an attempt to diminish that person's sense of self (Wiggins 1974). One example is a young child damaging another's favored toys in an attempt at retribution for perceived injustices or to dominate and control the other. Another class of examples involves defacing or destroying someone else's material possessions to communicate a threat of harm to the owner. Cross-burning on the lawns of African Americans, the painting of swastikas on synagogues, and the systematic appropriation or destruction of property during wars are all methods of terrorizing and violating the target groups. The third and most extreme class of examples of this type of destruction involves hurting or killing a beloved animal or human that is a part of the target's extended self. The subject of a stalker's obsession may be in less danger of harm than the subject's loved ones. And, as noted previously, a perpetrator of intimate partner violence may threaten, harm, or kill his partner's pet as a way of terrorizing and diminishing her. In national or tribal conflicts, raping and killing women and children is a common tactic used to subjugate the enemy.

Closely related to involuntary loss of possessions that are parts of the extended self is the forced relinquishment of such possessions because of financial hardship or life transitions. Examples include having to sell treasured objects such as a home, car, or artwork because of job loss or divorce and giving up friendships with former lovers at the re- 
quest of a new partner. One reason why role transitions can be so stressful is that one is often forced to relinquish familiar and highly cathected parts of the extended self before the required self-transformation can be completed. A new job in another city necessitates leaving behind the old job role, the roles of everyday friend and colleague, the community, the domicile that had become home-all of the people, places, and social roles that become parts of the extended self over time. Inevitably in such role transitions, there is a period of liminality (von Gennep [1909] 1960) when one is "betwixt and between" - after the old extensions of self have been relinquished and before the extended self is recreated. If life transitions that are voluntary and even welcome-for example, marriage, birth of a child, job promotion, graduation - are difficult because of the losses and period of liminality, those imposed by misfortune are far more daunting, in part because the path of self recreation or restoration is not clearly delineated nor even a given.

How objects become incorporated into the extended self has been explored extensively, in theory (e.g., Belk 1988; Sartre 1943) and empirically (see Belk 1988 for a review). Sartre (1943) describes three ways this incorporation may occur: control, creation, and knowing. Belk discusses a fourth way, especially relevant to this study: contamination. Control includes appropriating an object for one's own use, achieving mastery over it, or overcoming or conquering it (see Schillinger [1988] for an example of control in an abusive relationship). Enslavement and imprisonment are means of owning humans; the humans may become extensions of the self, and identity as a conqueror may be incorporated as an enduring trait. A second way of incorporating an object into the extended self is to create it; in Sartre's view, buying is another form of creation, and thus, money may enlarge sense of self because it increases possibilities for self-extension. While not discussed by Belk or Sartre, playing a part in another person's transformation or growth is another form of creation that may engender a sense of ownership of the one transformed. This would help explain the difficulty teachers and coaches sometimes experience in letting go of an exceptionally talented student or the pain and rage of a partner who has facilitated a loved one's growth (e.g., by financing postgraduate education), only to be left behind by the person transformed.

A third way of incorporating an object into extended self is to gain intimate knowledge of it (Sartre 1943). A neighborhood, a bookstore or 
diner, a bicycle or car, a house, an animal companion-all may be experienced as a part of oneself after long years of intimate familiarity. Selfextension to include another human may occur through sexual contact (the Biblical sense of knowing); through long and intensely intimate familiarity with many aspects of that individual, as parents know their children; and through shared history and experiences during many life events, as siblings or lifelong friends come to know one another.

A fourth means of incorporation into extended self-symbolic contamination - is involuntary, unwelcome, and often experienced as a violation. Common examples of interpersonal contamination include violating personal space, unwanted touching, staring, uninvited talking, noise pollution, and odor (Goffman 1961). An extreme form of contamination is rape; the victim involuntarily incorporates the perpetrator into her extended self. The depth and lasting nature of the contamination are evidenced by the victim's feelings of violation, shame, guilt, grief, and rage and are supported by society's tendency to blame the victim. Nonsexual stranger assault may result in shorter lived feelings of contamination in part because the victim is less likely to be stigmatized as contaminated.

\section{Research Context and Analysis}

To have sustained access to abused women, a female member of this research team volunteered at a local support agency (see Loseke [1989] for more details on the use of qualitative methods with social services). Located in a large metropolitan area in the northeastern United States, this agency was created and managed by a nonprofit community organization providing free services to abused women and their children. In addition to emergency shelter, services include crisis counseling, support groups, legal advocacy, and referrals to job training programs and other resources that promote economic and emotional well-being. Most of the women served by the organization are between the ages of twenty and thirty-five, with two or more children. The safe house, the primary access point of our interviewees, serves as temporary refuge to approximately one hundred abused women and their two hundred children each year.

The researcher/volunteer was required to participate in a sixhour training program, which provided an overview of how abuse of 
women (emotional, physical, or sexual) affects the victim and her children. As an agency volunteer, she served several functions. For example, she spent approximately four hours a week at the safe house and agency headquarters during a six-month period, interacting with the women and their children, providing emotional support and, on occasion, advice about parenting. In her capacity as a licensed psychologist, she also served for two years as a child psychotherapist and clinical supervisor of staff members and interns conducting psychotherapy with children and their mothers. This work at the safe house and the agency offices brought her in direct contact with about forty abused women, and she supervised an additional thirty cases. Clients associated in any way with her clinical work, whether directly (as parents of child patients or as participants in parenting sessions) or indirectly (in her supervisory capacity), were not invited to participate in the study for ethical reasons.

Six women at the safe house were formally interviewed at their convenience; the sessions were audio-recorded, and the tapes were transcribed. ${ }^{1}$ To gain further insights on developing perspectives and themes, fifteen other women residing at the safe house were interviewed regarding their experiences of abuse by the partners from whom they were taking refuge. Detailed written notes on these conversations were kept. The women were all questioned about what brought them to the shelter, about the nature of the abuse, and about their plans for the future. If the information did not come out spontaneously, the researcher asked about the roles played by possessions and consumption in all three areas. These women comprised Whites, Hispanics, and African Americans ranging in age from twenty-three to forty-five so that no particular subset dominated our results. Additionally, some had less than a high school education, while others had attended college. Most had young children with them. Some had no income, while others had steady jobs; all were struggling to meet basic survival needs.

To maximize the informants' diversity and broaden our thinking, we sought additional informants with more "upscale" lifestyles (Lempert 1994). Thus, the same female researcher also formally interviewed fifteen women from affluent suburbs who responded to a classified advertisement placed in two local newspapers during a period of one month. These informants were White and ranged in age from twenty-three to fifty-three. Their education levels ran the gamut from high school diploma to Ph.D. Most had children. And while some in this second group 
of informants were struggling to improve their financial situations, all were able to meet basic needs; a few were affluent.

To preserve the women's anonymity, aliases were assigned by the investigator transcribing the interviews, and these pseudonyms, along with approximate age and location, are used to inform respondent comments. The institutional review board at the lead author's university agreed that this was the wisest course of action, since protecting the confidentiality of the informants was of paramount importance. We also honored the requests of three women that we not include any of their direct quotes. They feared that their partners might come across a resulting publication of our findings and recognize their identities from specific incidents or turns of phrase.

Analysis of these data was consistent with Patterson, Hill, and Maloy (1995), and it involved working through four successive stages by two additional researchers along with the researcher/volunteer. The first stage required reliving the interview experience with each respondent by reading the transcription of the interview until the researchers felt a sense of "empathic knowing" of the informant as a potential or actual victim of intimate partner violence. The second stage required the summarization of each informant's experience with an emphasis on the role played by possessions and consumption. To the extent possible, verbatim comments from an informant were used to render this synopsis. The third stage involved searching for themes that were common across informants. The fourth stage required that relationships among the themes be explored to develop a comprehensive understanding of intimate partner violence from a consumer-behavior perspective. To this end, each transcript was reviewed again in an attempt to discern the interconnections among themes as well as to look for negative and qualifying evidence that failed to support this gestalt. The results presented in the next section represent the consensus of the researchers negotiated during the course of ten meetings.

\section{Emergent Themes}

While every woman's situation was different, commonly reported experiences included terror; loss of self, dignity, security, and possessions; physical and emotional pain; uncertainty about when and how their abusers would strike; and what, if anything, they could do about 
it. Prominent in their accounts were abuser self-transformations through substance abuse, leading both to increased violence and evasions of responsibility for it; symbolic destruction of the professional, social, and emotional aspects of the women's sense of self; and harm to animals and children, the most significant aspects of their extended self.

\section{The Cycle of Abuse and Extended Self}

It is common sense that victims of assault, rape, and other personal crimes would decline further voluntary relationships with perpetrators who were not previously known to them. The reality for our respondents, however, was that most had developed strong emotional ties to their abusers before the violence began. This is consistent with Koss et al.'s (1994) summary of studies showing that 73 percent to 85 percent of abused women did not experience violence until they had married the abuser. Furthermore, many of our informants first experienced the abuse as an infrequent and baffling aberration. Only gradually and over time did the abuse escalate; even then, it was not necessarily continuous, but periodic. Thus, life with an abusive partner often has periods of relative calm. Such experiences are consistent with other descriptions of life with an abuser (see case histories in Barnett and LaViolette 1993). Walker (1984) characterizes the abuse that many women experience as a "cycle of violence" in which abuse episodes are preceded by a period of stress and tension buildup, followed by the actual abuse. Moreover, as physical abuse has increasingly moved from the private domain to the public domain in the past three decades, abuse has moved to the "extended self" in terms of the destruction of possessions and work identity and the threats to harm cherished others or pets.

Perpetrator self-transformation through substance abuse. The causes of a particular violent episode are difficult if not impossible to pinpoint. For victims, the relevant issue may be less one of causality and more one of predicting episodes of violence to protect themselves. Those informants who could predict their partners' violence often related it to substance abuse. For example, abuse was frequently associated with the abusive partner's alcohol consumption, as experienced by Beatrice (age twenty-nine and living in a safe house): 
The night that led me to here, he'd been drinking. He started a verbal argument with me, and I tried to leave the house with the kids, and he wouldn't let me, and he picked me and my younger son up, he told us to obey him. He picked me up and threw us. He threatened to snap my head off. ... His drinking got worse over the years. The patterns, his behavior. The patterns increased his behaviors, whatever stresses he was feeling, he had stopped communicating to me. If there was something he wanted me to change or do or be or whatever, he wouldn't talk about it. He would hold it in, and he would go drink, and then it would become "Oh, it's time to explode."

While the association between substance abuse and intimate partner violence is virtually undisputed (Testa, Quigley, and Leonard 2003), whether substances create physiological changes that cause violent behavior is not (see Flanzer [1993] for an opposing perspective). Arguing that few drugs besides amphetamines appear to cause human violence, Gelles (1993) describes two studies that support the association- notcause view. First, MacAndrew and Edgerton (1969) argue that the effects of alcohol are culturally determined and related to belief systems. They found that in cultures that believe drinking is a depressant, drinkers exhibited passive behaviors, whereas in cultures that believe drinking reduces inhibitions, drinkers became uninhibited. Second, Lang et al. (1975) found that aggression was related to drinking only as a function of expectancy (i.e., those who thought they were consuming alcohol were more aggressive than those who did not).

Thus, the role played by alcohol and drugs may not be causal, but justificatory. Where there are sociocultural norms, such as in much of North America, that drinking and drug use disinhibit violence, they may be offered as excuses for irresponsible behavior: "I didn't know what I was doing. I was too drunk" (Barnett and LaViolette 1993; Bograd 1988; Gelles 1993; Koss et al. 1994). It is as if the abuser blames the violence on this "other" self that shows up when under the influence of alcohol or when in need of release through the use of drugs.

Even if alcohol and other mind-altering substances are causally linked to violent behavior in some individuals, it may be argued that those who consume it regularly have ample knowledge of its effect on them. Furthermore, if such an individual cannot resist ingesting it on occasion, despite foreknowledge of its destructive impact, he could still avoid violence to his partner by removing himself from her presence during his 
drinking episodes. That perpetrators of intimate partner violence do not do so suggests that they do indeed consume alcohol and other such substances both to access a disinhibited and violent self and to disown the violence afterward.

Women as property. The women themselves were treated as possessions by their abusers, to be used as needed. Laura (thirties, suburbs) expresses her commodification by her husband as follows:

He basically saw me as a trophy. I was just something else he acquired.

Situated against the historical backdrop, this is hardly surprising as wife assault was a right rather than an illegal behavior in parts of the United States until the twentieth century (see Jones [1994] for a discussion of relevant legislation). Such abuse, even if nonlethal, may have lasting negative consequences. In particular, disfigurement may destroy a centrally important aspect of a woman's core identity, given that females are so frequently judged and accepted or rejected based on their physical attractiveness. Even if they survive, or physically heal completely, the psychological effects can be considerable, as abuse is fundamentally an attack on self-identity (Belk 1988). And attacks on the physical self can temporarily diminish the significance of objects that are part of the extended self. Rachel, a suburban housewife, discussed an earlier period in her life when her husband was abusive and then moved out. Explaining to the children where their father was created an additional level of anxiety, counterbalancing some of the relief felt by the reduced threat to her physical self. Possessions did not seem to matter much at this time, and some things were sold that she later regretted not having.

The lingering death of the "women-as-property" perspective has forced issues that were at one time solely private into the public domain, and signs of physical abuse are less likely now to be ignored by the general public. "Historically, male battery of women was untouched by law, protected as part of the private sphere of family life. Over the past twenty years, however, ... battery is no longer perceived as a purely 'private' problem, and has taken on the dimensions of a 'public' issue" (Schneider 1994, 36-37).

There are still pressures on women to conceal physical abuse to the extent possible to protect their jobs and avoid stigmatization if they disclose problems of intimate partner violence. The public aspects of physical violence are receiving the focus of law, and more private issues such as damage to the extended self remain hidden. In general, outsiders are 
not privy to broader patterns of social power, patterns of power within the relationship, and the complexity of the woman's life needs and struggles (Mahoney 1994).

Symbolic destruction of extended self-special possessions. It was common for our informants' partners to exert control or punish them by appropriating, systematically damaging, or outright destroying possessions that represented or had been incorporated into the women's core and extended selves. The following excerpts from Patricia (twentyseven, safe house) and Amy (mid-thirties, safe house), respectively, illustrate the abusers' efforts to prevent their partners from succeeding in the workplace and, in addition, to humiliate and cast doubt on their view of themselves as competent, independent adults:

He would a lot of times just take everything in the closet and just throw 'em. ... I started putting some things into my kids' closet because I don't have much clothes anyway, and if he was destroying these things.

Debra Lynn Stevens (DLS): So he focused on the clothes?

Yes, because he knew that would handicap me. ... Especially, he focused on my work clothes because I work in the nursing field. So, he knew that job meant a lot to me. So, he knew I didn't have so much money. "She's got to buy work clothes. She needs that for her job." So he would focus on that.

As I started collecting my things to start back to work, when he would have his temper tantrums, he would break them. Like my perfume and my makeup, which would be very expensive for me to replace, so it always kept me in a situation where I would have to replace things, and I wasn't quite all together to go to my auditions, so it kept me kind of homebound.

Another safe house informant's partner either destroyed or concealed her birth certificate and Social Security card, documents that are essential for many adult transactions. These acts may be experienced as an attack on the valued professional or financially autonomous self, which in American culture is symbolic of adult status (Arnett 2000). When a batterer systematically destroys the possessions that are both means to and symbolic of his partner's autonomy, he is getting rid of proof of her agency and showing her that there is no part of her or her life he cannot control. It is as if he is attempting to reduce her to the status of a slave, prisoner, or very young child. 
Other special possessions often targeted represent passionate interests or talents central to the victim's self-identity, as Flora (forties, suburbs) attests below:

This is the hardest thing. I paint; I had almost a thousand pieces of artwork. Some are mine, some we collected ... most of them were mine. He destroyed them. ... I did a painting that was not one of my better ones. It was a blond woman ... and I came back one day, and it was slashed and had heel marks. And then other ones, but not as bad as that... The other ones were thrown and broken; this one was mutilated in a different way....I have a doll collection; he bought me the dolls. That was smashed too, the blond doll, the same thing as the painting, the eyes were poked out.

The artwork is evidence of Flora's talent, which is not under the abuser's control and, hence, is a provocation to him. The distinctive nature of the damage to the painting and doll bearing a physical resemblance to Flora are clearly attempts to terrorize her. The destruction of the eyes may also symbolize the perpetrator's wish to obliterate his partner's pleasure in the world around her and competency to navigate it with ease or his desire that she not see the truth about him or their relationship. The collections are special because they represent the relationship itself; hence, the damage to them may communicate the perpetrator's intention to end it violently.

Destruction of victims' property occurred frequently, sometimes with cool premeditation, other times in what appear to be acts of rage. Irene (thirties, suburbs) provides a chilling example of the latter:

He took my pocketbook with my keys, and some of them were bent real bad. He took my pocketbook and he beat (it) against the floor so hard that the keys went through the leather. There are cuts all over my floor. Beat in one of the kitchen cabinets. I had to have it replaced. Every door in my house has either got a crack in it or the hinges are all off, from punching the door; you can see all the paint in the corner that crumbles off. They all have little hairline cracks in them.

When a woman leaves the house, she usually takes her pocketbook (for money and identification) and keys (to drive away, and to reenter the home at will); thus, the destruction of these objects may symbolize the abuser's fear and rage at the prospect of losing that which he views as 
an entitlement (unbounded access to "his" woman). Also, assaults on all of the doors in the house may communicate to the victim that she cannot shut him out or escape from him, physically or psychologically. Vandalizing the house, which is the couple's private, intimate space, may convey the message to the woman that the relationship exists at her abusive partner's pleasure and that, as such, may only be terminated at his will.

Special possessions that represent attachments to significant others (parts of the extended self) may also be damaged or destroyed. Isabel's parents died when she was a teenager, and she took care of her grandmother until she died at the age of ninety-six. Isabel (early thirties, suburbs) was especially attached to mementoes from both her mother and grandmother:

I had some things that were hers and things that were my mother's and they are precious to me, like antique perfume bottles and glassware. ... One of Frankie's favorite things to do when he was abusive would be to, he would pick up something that I loved and he would say, "I'm gonna smash it. I'm gonna smash it." And I would do anything, like "Oh my God no, that's my mother's." I would freak out, cry, beg him, like grovel on the floor at his feet. "Please. Please. Please don't hurt that. I'll do anything you want."

Possessions that are symbolic of attachments to people other than the abuser are typically targets for destruction. Several additional informants told of photo albums, crystal, and other mementoes that their abusers destroyed. An abuser may isolate his partner from family and friends in an attempt to sever her attachments to others and to gain greater control over her. Damage to possessions symbolizing those other attachments may simultaneously communicate his rage at her for loving other people and serve to wound her and diminish those aspects of her extended self.

These interviews suggest that an abusive partner may destroy any possession that represents a part of the woman's extended self not connected with him. It appears that perpetrators may selectively target symbolically significant possessions rather than mundane ones and damage or destroy them rather than hiding, selling, giving them to others, or simply discarding them. These latter tactics would not be nearly as effective at terrorizing the victim. 
Symbolic destruction of extended self-significant others. As noted earlier, some attacks were on animal companions and children rather than special possessions. Consider comments from Julia (forties, suburbs), Edith (fifties, suburbs), and Isabel (early thirties, suburbs), respectively:

The day he picked up and dropped my dog off the back porch, that was it. He definitely did things to hurt the dog. He, you know, intimidated him, scaring him.

We had two cats, the one cat, he was angry the one time. He grabbed her by the paw and threw her on the ground.... He like pulled her arm out of the socket.

As terrifying and painful as it may be to experience a partner's destruction of treasured inanimate possessions, animal abuse, a crime itself, crosses the line into sadism toward the animal and in addition constitutes an especially severe form of psychological abuse of the woman victim.

Frequently, the abuse involved children, especially the abuser's stepchildren, as described by Beth (early thirties, suburbs) and Ada (forties, safe house), respectively:

There were incidences where he hurt Erica [age seven at the time of the interview]. Like he came in the house once and he, I was sitting down and he poured water on my head. She got really mad and she yelled at him, "you big brat," and he kicked her in the butt and she flew across the room. She was a little thing, flew across the room, then he picked her up, and threw her down on the couch and of course I ran over screaming, you know, and I pulled him offa her.... Erica tried [to intervene] a couple of times, but because he would hit her, she stopped ... cuz I didn't want her to get caught in between, you know, it wasn't his daughter. She was from my first marriage, and even though he legally adopted her ... it's not his flesh and blood and it's different.

My daughter [abuser's stepdaughter] has long, you know long hair. Her hair was growing, he took a pair of sewing scissors and cut all her pretty curls off.

When a perpetrator of intimate partner violence abuses his partner's offspring, he may be attempting to incorporate the child into his extended self by the process of contamination described by Belk (1988). In essence, 
mother and child become his property, not to be treasured but to be used to satisfy his need for power and control over others.

\section{Coping with Violence}

A common reaction to hearing that a man abuses a woman is "why doesn't she just leave him?" From the decontextualized perspective of an outsider, this may seem obvious and well meaning. Yet this view also contains some underlying assumptions that could further victimize abused women (Baker 1997). That is, women are seen as having just two choices: leave to escape the violence, or stay. If she does not leave, it is thought that she must somehow enjoy the violence or derive some pathological psychological benefit from it, making her undeserving of support (Okun 1986). Unfortunately, from a victim's perspective, this so mischaracterizes the situation's realities that it may prevent her from receiving the types of support needed to escape the violence.

The "just leave" response seems a bit simplistic when compared to the societal norm that love is an acceptable reason for trying to work through interpersonal troubles. It is surprising that women who love their partners and hope to get them to stop battering are treated as crazy or masochistic and that "staying" often is judged by the courts as a denial of the existence of abuse (Mahoney 1994). Battered women who killed their abusers have been required to account in court for their failure to leave. Clearly, there is much need for societal understanding of why women stay.

Although many of our informants had left their abusers at least temporarily, a permanent break was difficult for several reasons. For example, concern for the safety of animal companions made leaving difficult. Harriet (late twenties, suburbs) recounts her untenable situation:

I couldn't leave my dog with him, and I felt that I couldn't leave because I couldn't find anywhere that I could move to where it would take the dog. He used to tell me that he was going to go down to [a local] Quarry and he was going to throw the dog in the water and that each time his paws came up, he was going to beat his paws with a stick so he couldn't get out.

The abuser would also make attempts to regain a positive relationship by various means, including pleading for another chance and rela- 
tively long respites from the violence. Isabel (early thirties, suburbs) provides an example as follows:

And it does look like, oh, this [abuse] is just an exception. The way he would cry and the way he would talk about his family and his dad doing this to his mom and you know ... I felt guilty.

The abuser would often make attempts to win back the victim's affection. In a few instances, informants, including Beth (early thirties, suburbs) and Edith (fifties, suburbs), respectively, reported receiving gifts:

The man, to this day, spends tons of money on me. Always trying to buy my love, I guess.

DLS: What sorts of things does he buy you?

Jewelry, perfume, flowers, furniture, clothing, everything. You name it, groceries. He'll go out and buy bags of groceries and leave them on the front steps, pizzas for the kids on Friday night, always giving the kids tons of gifts and things.

DLS: Did he ever buy you guilt gifts?

Oh yeah, oh yeah, all the time. And I mean for months it would go on. Oh, the first gift he bought me after beating me up was a little chain necklace that had a charm on it with a man and a woman and he had both of our names engraved on it.

Most informants did not mention such gifts, but that does not necessarily mean that they were not given. Gifts may have been given to help restore the relationship, but, if so, they were not especially effective in persuading the recipients interviewed. Gifts were more likely in the case of suburban informants, perhaps because more financial resources were available. However, greater financial resources did not always result in gift giving, as noted by Isabel (early thirties, suburbs):

[Did he buy you gifts and stuff after he beat you up?]

No, he wouldn't even buy me gifts like for Christmas. ... Frank was terrible with money, he probably would have bought me gifts if he wasn't as bad with money. But he just spent all his money. Frank would get his check and cash it on the way home. Spend it spend it spend it and then give me like a hundred bucks out of a five-hundred dollar check. 
In general, leaving may end the violence, but it may also lead to significant loss - of the good times, the positive emotional connections, the home and its contents, the partner and children, and substantial economic resources. Given that these elements often constitute the extended self (Belk 1988), few individuals would abandon them easily. Furthermore, leaving fundamentally conflicts with women's gender socialization and social mores as articulated by Harriet (late twenties, suburbs):

I was brought up that family problems are kept at home, family problems. You don't tell your school, you don't tell your friends, you don't tell, it's family.

When the actual leaving occurs, conditions are such that family norms may be ignored, but at a price. Harriet left her young baby with her abuser to gain her independence, but it took a three-year custody battle to regain a stable living situation (she obtained sole physical guardianship).

Women learn to use relationships (and their preservation) as a critical decision-making criterion and view them as cherished possessions (e.g., Gilligan 1982; Patterson, Hill, and Maloy 1995). Also, women learn to internalize and invest in certain roles such as wife and mother. Fischer $(2000,186)$ noted the deeply embedded feminine role in North American society: "The care-giving role in general, and the mothering role in particular, are among the most sanctified across a broad range of collectivities, even those where the notion of the patriarchal nuclear family is not resonant." Mahoney (1994) discusses a woman who wanted no part of her former abusive husband from whom she had been divorced for ten years, but who still regretted her children's loss of closeness with their father. Exiting these roles, especially when the new roles (and hence self-definition) are uncertain, may be extraordinarily difficult (Ebaugh 1988).

Second, the extreme options of "stay and endure the violence" and "leave and escape the violence" may form an inadequate and unrealistic choice set. For example, a woman might wish to stay and end the violence. The assumption that if a woman leaves, she will be safe may be tragically wrong; women who leave their abusers may be stalked, injured, and/or killed. Browne (1987) estimated that more than half of the women who leave abusive relationships are followed, harassed, or 
further attacked after separation and that more than half of the men who killed their wives did so after the partners had separated. Abused women do not "leave" to a witness-protection-like secure environment. Even if they find an unknown residence, they may still have the same workplace; as one might expect, the workplace is often a locus of attacks by a batterer (Mahoney 1994). One may well ask, why should she be the one to leave? Some suggest that solutions focusing on women leaving rather than apprehending or counseling the perpetrators is inappropriate (Berk 1993; Tavris 1992). They may simply set the stage for another victim to be abused.

Third, the harsh reality for many abused women who wish to do so is that leaving, especially permanently, requires significant external support-financial, legal, psychological, and medical-to which they do not automatically have access. By leaving, they may be giving up far more than they will gain. Fourth, the serious psychological and emotional effects of abuse may impair a victim's ability to view the abusive situation "objectively" and thus take appropriate action (e.g., Follingstad et al. 1990; Walker 1979). From the perspective of many of our informants, the meaningful issue is less about leaving and more about ending the violence or gaining necessary resources to stay safe from the abuse.

Strategies for ending the violence. Consistent with Bowker's (1988) findings, our informants wanted the violence to end and had entertained notions of leaving as a solution after the abuse began. However, a variety of other strategies to reduce the violence also were employed. Beatrice, whose husband "exploded" after he would drink, co-consumed alcohol with her husband as a preventive action. Emily, whose drunken husband put her head through a wallboard, distracted her husband by seducing him; and Flora, whose husband was predictably abusive when he drank, kept away from the house during these times. More than one informant used or acquired a weapon for defense in an attempt to empower themselves in relation to their abusers. Patricia (twenty-seven, safe house) described grabbing a knife for defense:

He was holding the baby and he shoved me. And at that point, I started to lose it. I said, "You know what, I don't care what names you call me or my family, but I'm sick of you putting your hands on me. That's one thing I am not gonna take from you." 
That's all he needed. That was the opening that he needed. So he started gettin' in my face and pointing his finger in my face, like, "Go ahead, what are you gonna do?" And it was like I was just tryin' to get away from him because I didn't want the kids to see, and I was tired, I was burnt out emotionally. I was tired of that life. So I tried to go upstairs, and he's following me, getting in my face. And I think at one point he kinda like, shoved me. I was just like, "Get off of me." So then, he pushed me again, and I ran and grabbed a knife, and I ran all the way up and jumped in his face with it, and he jumped back. ... It was the first time I took a knife to him.

Christina (mid-forties, suburbs), whose boyfriend had been convicted of assault charges and served a year in the county jail, purchased a gun when he was about to be released:

Here we're coming down to [the day of my boyfriend's release], the day is approaching and my protection order is wearing out. So I renewed it, so I got a backup. ... So I thought, OK, I need to be doing something about getting myself protected, so I got a gun permit. ... I got the gun training, and I got the gun, and I got comfortable, and I load it and unload it and dry fire it and all this stuff every day, and I haven't been shooting a lot, but I'm good.

Concerns about the ultimate efficacy of the use of weapons for selfdefense notwithstanding (e.g., Blair and Hyatt 1995), it is not surprising that some informants used weapons to protect themselves. In addition to serving the self-defense function, weapons may empower women and/ or diminish their sense of being controlled by their abuser, thus helping them reclaim adult autonomy.

The role of economic reality. While a number of factors determine who leaves, usually it is the battered woman who must pack up and go to remove herself and her children from her partner's control. However, negative economic consequences are a key reason why women who wish to leave the abusive relationship may not "just" do so (e.g., Barnett and LaViolette 1993; Okun 1986). Although women of all economic circumstances suffer abuse, poor women may find it especially difficult to make it on their own; they may not be able to replace their destroyed possessions; they may have had to leave with very few possessions; they may not have a safe house to go to, or when their time there expires, 
they may have no "second stage" or alternative housing; they may have no job prospects and/or childcare options if they have young children (see Cunradi, Caetano, and Schafer 2002; Thoits 1995).

The extended selves of our safe-house or urban informants generally involved "less" in a material sense than did those of our suburban informants. Attacks on the extended selves of the suburban informants were less likely to involve work identities and more likely to involve other special possessions, as indicated by the quotes provided earlier. Isabel, one of the suburban informants, was faced with much debt when she left her abuser, who at times was able to earn a substantial income. But he had a history of alcohol-related violations, resulting in the loss of his driver's license and a poor credit history, causing them to put most purchases in her name. Thus, despite their better material circumstances, the suburban informants usually faced some fiscal limitations of one sort or another. Furthermore, they faced a greater challenge in terms of finding a new life comparable to what they had previously. For example, going to a safe house or finding affordable housing usually meant that their children would need to change schools and that their standard of living would decrease considerably.

The informants who managed a household found entry into the workforce difficult and that their husbands often punished them by withholding child support, alimony, or other financial assistance. The fiscal realities for women seeking to escape violence are evident in the following comments by Joan (forties, safe house):

DLS: What would it take for you to stay away from him?

I need a job. I need some income. Look, these apartments out here are so high, and then you gotta have good credit for another thing to get in a apartment. My credit is so messed up, I can't do nothin'. ... The other day, I was feelin' so bad ... I asked myself "What am I doing in here?" 'Cause I know I'm not gonna be able to get no place. I know I'm not gonna make it out on my own. \$326 [a month] ain't gonna get me in a door.

DLS: That's true, but you might get a job, right?

Yeah, I might get a job, but that's no guarantee. I done been to so many places, looking for jobs, putting in applications. You get tired of doin' it. And you get disappointed, and you say, "What the hell is the use? Go on back to your abuser, go on take a little abuse." That's what happens. You keep going back. You keep goin' back, but I'm tired. I'm really tired. 
When discussing the difficulty of making it on her own, she also brought up the issue of medical care:

I tried to get into some kind of medical thing for me and my daughter... They won't give it to me because of his income. Now I just tried to go on medical assistance. I don't know whether they gonna give it to me or not.

DLS: What would happen if you got divorced?

He wants me to, but I'm not going to. ...Twenty years of my life he done took away from me, he could forget about me signing any papers about any divorce.

Joan was clearly conflicted. On one hand, she wanted to escape; on the other, her economic situation was precarious and hence her alternatives limited. It is not surprising then that part of her decision calculus included the long-term investment that she would lose (e.g., Rusbult 1980).

Other obstacles to escaping the violence. Perhaps the greatest challenge to the idea that a woman can just leave to escape her abuser is the high likelihood of subsequent attacks after a woman has left. Barnett and LaViolette (1993) cite National Crime Survey statistics that ex- husbands were responsible for 29 percent of reported wife assaults. Several of the informants did not believe that leaving an abuser ensured safety; the threat to their physical beings was counterbalanced by threats to their very uncertain "future selves" (Markus and Nurius 1986). For example, Danielle, a suburban informant in her mid-fifties, had never attempted to leave her husband and did not plan to do so. Contrary to common wisdom, she viewed her choices not as between staying in the violence versus leaving to escape the violence but as staying and working to end the violence versus fearing for her life. Danielle was convinced that if she were to leave, her abuser would hunt her down and kill her or harm one of their children. Patricia (twenty-seven, safe house), who did leave her husband and was employed and doing well financially, expressed continuing concern about her safety:

At this point, well, I guess I've been goin' through the worst, because I filed a protection order against him, which is something I never thought I would do. ...He called me one time while I was at the baby-sitter's, and threatened me. ... His exact words were, "Bitch, I'll fucking kill you." And I believed him. You know, he threatened me before, but when it came to the kids, I did not 
know what frame of mind he was in, because at that point, I think he realized that I wasn't coming back, and I guess he thought I was tryin' to keep his kids from him. ... The next day I went and filed a protection order.

Yet protection orders, which must be granted by judges, are not always effective against batterers. Joan (forties, safe house) recounted the following about a friend:

Two weeks ago, this girl dropped a 218 on her boyfriend, and she's dead now. ... That boy sure beat her something terrible. He beat her so bad, he put her in the hospital for almost a week. She come out the hospital. She dropped a 218 on him, and two days later, he killed her.

\section{Reconstructing Identity}

Despite significant financial obstacles, some women had made substantial progress in redefining themselves and their lives. Both Patricia and Mary spoke of concrete plans for the immediate future, plans that they were already implementing at the time they were interviewed. Both felt that they had been through the worst portion of their lives, that leaving the abuser was the only alternative, and that striking out on their own was their only chance at a satisfying, stable, and peaceful life. Patricia (twenty-seven, safe house) was young, healthy, and employed, but was struggling to make ends meet:

I got my place, so I was proud of myself for that. I didn't think I'd be able to do that. I guess we should be moving in about a week and a half. And after I do that, I wanna really try and work on my goals, my educational goals. My skills.

DLS: What are those?

Well, I'm in the nursing field. I had wanted to become a nurse, but I don't know if I could really do the schooling right now because of the baby and everything. But I'm tryin' to work on, maybe I could get a certificate, go to [county community] college. Just something so I could try to get a little more education, more skills to boost my income some, because right now it's a tight squeeze, it's a tight fit based upon my income.

Her difficulties and fears notwithstanding, she was able to envision herself as a competent woman with professional aspirations. 
I didn't think I could get my own place on my own. I didn't think that I had the credit. I didn't know if I had the ... It was just a whole different world. It was like, "Okay, if you do this, you're out on your own. You have three kids to support. It's just you. You've got nobody else to lean on. It'll be the first time you're out there on your own." And I knew when I made the commitment to come here that I wasn't going back. That's what I told him. ... I said if I were to come to the safe house, that I have to do a total 180 on my life in thirty days. And thirty days is not a lot of time.

When she discussed her ideal future home, Patricia responded with a detailed and vivid description, indicating that she had given it much thought and that she could imagine herself and her children living there and enjoying the freedom to reveal themselves without fear of rejection or reprisals:

You know, all I really want-I look at these homes around this area, 'cause I work in [the local neighborhood], they're beautiful, and [I] just like land for them [the children] in the back to just do what they wanna do. If they wanna roll on the grass, if they want one of those jungle gyms. I would love a single home and just for them to have a nice playroom, to have anything they want. I don't need a pool and all that other stuff; I just want things for them, just so that they're happy. ... The one thing I want for me is I want a big kitchen, 'cause I love to cook. So if I have my kitchen and they have their area in the back, their yard and their space, that's all I want. I mean, I'm a pretty simple person. I've never really gotten into the material things, but a home ... I want that to be settled. To be happy, to have peace. They could rip roar and not have to worry about anything. I mean I can come home, throw my shoes off. If the kitchen's a mess, who cares? It's mine. Nobody can say, "Get out!" ... and I'm starting. And I'm starting small, but you gotta crawl before you walk, they always say.

Mary, a twenty-three-year-old safe-house informant who had escaped with her four small children from her crack-addicted partner, responded similarly when asked about her plans for the future. She expressed the strong conviction that her current living environment was the worst possible circumstance and that any alternative she could envision was preferable to her five years with her abuser. She informed the interviewer that she had passed two of the tests for her GED and would take the remaining ones soon. At the time of the interview, she was looking for a place to live. Her longer term goal was to become a paralegal. Like Patri- 
cia, she had begun to see herself as a woman worthy of respect and capable of achieving professional career aspirations. A children's services staff member told us later that Mary used her experiences at the safe house very well, learning how to forge positive and loving connections with her children and how to nurture, guide, and protect them. Though Mary herself had suffered childhood maltreatment, she was able to internalize the alternative model of parenting demonstrated by the safehouse staff.

\section{Conclusion}

This research demonstrates that domestic violence against women involves more than just the physical self. Damage to the extended self is less public but also very traumatic. A woman's strategies for coping with the violence are influenced by various consumption-related resources. Although our informants' situations were very much affected by basic consumption issues such as the loss or destruction of their personal possessions, their financial independence, and their income earning potential, the more fundamental issue relates to the self and extended self-control of self, preservation of self, loss or destruction of self, incorporation of self into another's extended self, and so forth. A better understanding of the role of the self and extended self in our research context has important theoretical and practical implications.

First, introducing the concepts of the self and extended self can contribute interesting insights to the literature on intimate partner abuse. For example, they shed light on the psychological strategies used by the batterer in his efforts to control his partner and help answer the relatively under-researched question of "why doesn't she just leave?" Such analyses can also clarify the meaning of "leaving" - that it involves more than leaving a physical location and one individual, presumably for safety. It also means a potential loss of self as defined by invested relationships, treasured possessions, home, and comfortable socialized roles such as wife and mother. Finally, it also means future uncertainties, including uncertainties about safety, and the availability of resources needed to repair, rebuild, and sustain the self through a transitional period and beyond.

Second, examining the extended self within the context of intimate partner violence against women suggests opportunities for further de- 
veloping Belk's (1988) theory of the extended self. For example, as currently explicated, the theory is oriented generally toward nonviolent, less extreme forms of possession. Our research extends the premise that outside some range of normality and acceptability, consumption, possessions and the extended self can take a violent, pathological turn (Athens 1974). Furthermore, this research suggests that there can be significant physical and psychological effects from being incorporated into another's extended self. Investigating the extended self within other such consumption contexts may enhance this paradigm.

Third, understanding abuse as a problem involving the self has consumer policy implications. Despite arguing that issues relating to the self and extended self help explain why women do not necessarily leave their abusers, we are in no way suggesting that remaining in an abusive relationship is a desirable outcome. But moving forward with a damaged and more restricted extended self is extremely difficult. The women have left an awful situation, but embedded in that situation were their former selves. Identity reconstruction under conditions of the loss of one's former relationships and possible threats to one's safety may be seen as mission impossible.

For many women, permanently ending these relationships may be the only way to ensure their safety. This is more likely to occur if such a move does not entail further debilitating risks and losses, implying the need for more extensive social resources. More shelters are needed, especially community-based shelters that serve the needs of minority women. Shelters frequently restrict the amount of time a woman may spend there to about three or four weeks. Clearly, this timeframe is insufficient for a woman to repair her self and generate resources needed to sustain an independent future. Transitional resources are needed to help women acquire basic consumer products such as health insurance, food, bedding, clothing, housing, and utility subsidies and assistance, as well as continued protection and legal services.

For long-term independence needs, abused women need job training and child care services. Women who seek employment after experiencing abuse and/or being out of the paid workforce frequently need support to regain their confidence and upgrade their skills. In addition, they need affordable childcare options. Through the provision of these services, women may be able to overcome financial obstacles as well as attacks on their identities by their abusers and find the empowerment necessary to forge new and independent selves. 


\section{Note}

1. While most ethnographers prefer participant or nonparticipant observation of behaviors under investigation, their use was deemed impossible within this violent interpersonal environment. Thus, our selection of contextualized interview data to represent the primary information source was an appropriate compromise.

\section{References}

Alderson, W. 1957. Marketing Behavior and Executive Actions. Homewood, IL: Richard D. Irwin.

Arnett, J. 2000. Emerging adulthood: A theory of development from the late teens through the twenties. American Psychologist 55 (5): 469-80.

Ascione, F. R. 1998. Battered women's reports of their partners' and their children's cruelty to animals. Journal of Emotional Abuse 1 (1): 119-33.

Athens, L. H. 1974. The self and the violent criminal act. Urban Life and Culture 3 (April): 98-112

Baker, P. L. 1997. And I went back: Battered women's negotiation of choice. Journal of Contemporary Ethnography 26 (April): 55-74.

Barnett, O., and A. D. LaViolette. 1993. It could happen to anyone. Newbury Park, CA: Sage.

Belk, R. W. 1988. Possessions and the extended self. Journal of Consumer Research 15 (September): 139-69.

Berk, R. A. 1993. What the scientific evidence shows: On the average, we can do no better than arrest. In Current Controversies on Family Violence, edited by R. J. Gelles and D. R. Loseke, 323-36. Newbury Park, CA: Sage.

Blair, M. E., and E. M. Hyatt. 1995. The marketing of guns to women: Factors influencing gun-related attitudes and gun ownership by women. Journal of Public Policy and Marketing 14 (1): 117-27.

Bograd, M. 1988. How battered women and abusive men account for domestic violence: Excuses, justifications, or explanations. In Coping with Family Violence, edited by Gerald T. Hotaling, David Finkelhor, John T. Kirkpatrick, and Murray A. Straus, 60-77. Newbury Park, CA: Sage.

Bowker, L. H. 1988. The effect of methodology on subjective estimates of the differential effectiveness of personal strategies and help sources used by battered women. In Coping with Family Violence, edited by Gerald T. Hotaling, David Finkelhor, John T. Kirkpatrick, and Murray A. Straus, 80-92. Newbury Park, CA: Sage.

Bristor, J. M., and E. Fischer. 1995. Exploring simultaneous oppressions: Toward the development of consumer research in the interest of diverse women. American Behavioral Scientist 38 (4): 526-36. 
Browne, A. 1987. When Battered Women Kill. New York: Free Press.

Cunradi, C. B., R. Caetano, and J. Schafer. 2002. Socioeconomic predictors of intimate partner violence among white, black, and Hispanic couples in the United States. Journal of Family Violence 17 (December): 377-89.

Dobash, R. E., and R. P. Dobash. 1979. Violence Against Wives: A Case Against Patriarchy. New York: Free Press.

Ebaugh, H. R. F. 1988. Becoming an Ex: The Process of Role Exit. Chicago: University of Chicago Press.

Ellis, L. 1985. On the rudiments of possessions and property. Social Science Information 24 (March): 113-43.

Fischer, E. 2000. The ties that bind consumers, The consumer ties that bind. In Gender, Markets, and Consumer Behavior, edited by Jonathan Schroeder and Cele Otnes, 181-92. Association for Consumer Research: Provo, UT.

Flanzer, J. P. 1993. Alcohol and other drugs are key causal agents of violence. In Current Controversies on Family Violence, edited by Richard J. Gelles and Donileen R. Loseke, 171-81. Newbury Park, CA: Sage.

Follingstad, D. R., L. L. Rutledge, B. J. Berg, E. S. Hause, and D. S. Polek. 1990. The role of emotional abuse in physically abusive relationships. Journal of Family Violence 5: 107-20.

Gagne, P. L. 1992. Appalachian women: Violence and social control. Journal of Contemporary Ethnography 20 (January): 387-415.

Gelles, R. J. 1993. Alcohol and other drugs are associated with violenceThey are not its cause. In Current Controversies on Family Violence, edited by Richard J. Gelles and Donileen R. Loseke, 182-96. Newbury Park, CA: Sage.

Gilligan, C. 1982. In a Different Voice. Boston: Harvard University Press.

Goffman, I. 1961. Asylums. New York: Doubleday.

Hill, R. P. 1991. Homeless women, special possessions, and the meaning of home: An ethnographic case study. Journal of Consumer Research 18 (3): 298-310.

- 1992. Homeless children: Coping with material losses. Journal of Consumer Affairs 26 (Winter): 274-87.

James, W. 1890. The Principles of Psychology. Cambridge, MA: Harvard University Press.

Jones, A. 1994. Next Time She'll Be Dead. Boston: Beacon.

Koss, M. P., L. A. Goodman, A. Browne, L. F. Fitzgerald, G. P. Keita, and N. F. Russo. 1994. Male Violence Against Women at Home, at Work, and in the Community. Washington, DC: American Psychological Association.

Lang, A. R., D. J. Goeckner, V. J. Adesso, and G. A. Marlatt. 1975. Effects of alcohol on aggression in male social drinkers. Journal of Abnormal Psychology 84 (5): 508-18. 
Lempert, L. B. 1994. A narrative analysis of abuse: Connecting the personal, the rhetorical, and the structural. Journal of Contemporary Ethnography 22 (January): $411-41$.

Loseke, D. R. 1989. Evaluation research and the practice of social services: A case for qualitative methodology. Journal of Contemporary Ethnography 18 (July): 202-23.

MacAndrew, C., and R. B. Edgerton. 1969. Drunken Comportment: A Social Explanation. New York: Aldine.

Mahoney, M. R. 1994. Victimization or oppression? Women's lives, violence, and agency. In The Public Nature of Private Violence, edited by Martha Albertson Fineman and Roxanne Mykitiuk, 59-92. New York: Routledge.

Markus, H., and P. Nurius. 1986. Possible selves. American Psychologists 41 (September): 954-69.

McAlexander, J. H., J. W. Schouten, and S. D. Roberts. 1993. Consumer behavior and divorce. Research in Consumer Behavior 6: 231-60.

McClelland, D. 1951. Personality. New York: Holt, Rinehart, and Winston.

McLeod, B. 1984. In the wake of disaster. Psychology Today 18 (October): 54-57.

Morgan, A. J. 1993. The evolving self in consumer behavior: Exploring possible selves. Advances in Consumer Research 20:429-32.

Okun, L. 1986. Woman Abuse: Facts Replacing Myths. Albany: State University of New York Press.

Patterson, M. J., R. P. Hill, and K. Maloy. 1995. Abortion in America: A consumerbehavior perspective. Journal of Consumer Research 21 (March): 677-94.

Prelinger, E. 1959. Extensions and structure of the self. Journal of Psychology 47 (January): 13-23.

Rennison, C. M. 2001. Intimate Partner Violence and Age of Victim, 1993-99. Washington, DC: U. S. Department of Justice.

- . 2003. Intimate Partner Violence, 1993-2001. Washington, DC: U. S. Department of Justice.

Rindfleisch, A., J. E. Burroughs, and F. Denton. 1997. Family structure, materialism, and compulsive consumption. Journal of Consumer Research 23 (March): 312-25.

Rusbult, C. E. 1980. Commitment and satisfaction in romantic associations: A test of the investment model. Journal of Experimental and Social Psychology 16 (2): 172- 86.

Sartre, J. P. 1943. Being and Nothingness: A Phenomenological Essay on Ontology. New York: Philosophical Library.

Sayre, S. 1994. Possessions and identity in crises: Meaning and change for victims of the Oakland firestorm. Advances in Consumer Research 21:109-14. 
Schillinger, E. 1988. Dependency, control, and isolation: Battered women and the welfare system. Journal of Contemporary Ethnography 16 (January): 469-90.

Schneider, E. M. 1994. The violence of privacy. In The Public Nature of Private Violence, edited by Martha Albertson Fineman and Roxanne Mykitiuk, 36-58. New York: Routledge.

Snyder, C. R., and H. L. Fromkin. 1981. Uniqueness: Human Pursuit of Difference. New York: Plenum.

Tavris, C. 1992. The Mismeasure of Woman. New York: Simon \& Schuster.

Terry, D. J., M. A. Hogg, and K. M. White. 2000. Attitude-behavior relations: Social identity and group membership. In Attitudes, Behavior, and Social Context, edited by D. J. Terry and M. A. Hogg, 67-94. Mahweh, New Jersey: Lawrence Erlbaum.

Testa, M., B. M. Quigley, and K. E. Leonard. 2003. Does alcohol make a difference? Within-participants comparison of incidents of partner violence. Journal of Interpersonal Violence 18 (July): 735-43.

Thoits, P. A. 1995. Stress, coping, and social support processes: Where are we? What next? Journal of Health and Social Behavior 36: 53-79.

Tjaden, P., and N. Thoennes. 2000. Extent, Nature, and Consequences of Partner Violence. Washington, DC: National Institute of Justice and the Centers of Disease Control and Prevention.

von Gennep, A. [1909] 1960. The Rites of Passage. Trans. M. B. Vizedom and G. L. Caffee. Chicago: University of Chicago Press.

Walker, L. E. 1979. The Battered Woman. New York: Harper \& Row. . 1984. The Battered Woman Syndrome. New York: Springer.

Wiggins, J. W. 1974. The decline of private property and the diminished person. In Property in a Humane Society, edited by Samuel L. Blumenfeld, 71-84. LaSalle, IL: Open Court.

World Health Organization. 2002. Intimate partner violence. www.who. int/violence

Young, M. M. 1991. Disposition of possessions during role transitions. Advances in Consumer Research 18:33-39. 